\title{
Determining The Centers of Economic Growth And Regional Development Using Scalogram Analysis (An Empirical Study In West Halmahera Regency, Indonesia)
}

\author{
Jufri Jacob $^{1}$, Nonce Hasan ${ }^{2}$ \\ ${ }^{1}$ Lecturer of Magister Department of Economics Faculty, Khairun University Ternate City-Indonesia \\ ${ }^{2}$ Lecturer of Economic Faculty, Khairun University, Ternate City-Indonesia
}

\begin{abstract}
Each region has potentials and economic advantages that can be used as the source of its regional growth. The capability of each region to promote its own growth depends on its economic competitive advantages. This study is aimed to determine the centers of economic growth and regional development in West Halmahera Regency in the North Moluccas Province. The data used for analysis is secondary data which were collected using documentation method and internet browsing. The method of analysis used is scalogram analysis. The results show that among 9 subdistricts observed in this study, only 4 have the highest scores for socioeconomic infrastructures completeness. The subdistrict located in the central administrative area is the center of growth or growth pole, and the other 3 subdistricts act as the buffer areas. Based on scalogram analysis results, it is found that the growth of each subdistrict is relatively similar, with only 1 subdistrict that shows a relatively more advance growth in Hierarchy II with the highest Index of Subdistrict Growth (ISG) at 21.3433. The other 8 subdistricts are under-developed regions within Hierarchy III with the variable Index of Subdistrict Growth (ISG).
\end{abstract}

Keywords: Regional Development, New Economic Growth Poles, Scalogram Analysis, West Halmahera Regency.

\section{Introduction}

Regional development is an effort to build and develop an area to improve the welfare of its people by taking advantages of its natural resources, human resources, institutional resources, technological resources and physical infrastructures in an effective, optimal, continuous way. The main objective is to create equally developed regions to reduce inter-regional gaps (Adisasmita, 2008). Inter-regional gap, however, is a universal phenomenon (Rustiadi, and D. R. Panuju, 2009). Developmental approach that emphasizes on economic growth will cause investments and resources to be concentrated in larger cities and areas as the center of growth or growth pole, while hinterland areas are over-drained of their resources. This inter-regional gap is also occurring between subdistricts in West Halmahera Regency in the North Moluccas Province.

One strategy to reduce inter-regional developmental gap is by creating one area as the growth pole that spreads out to its peripheral or hinterland areas (Safrizal, 2012). These new growth poles can be significantly and vastly developed (Rustiadi and D. R. Panuju, 2009). A growth pole can only be developed in certain areas that have a variety of variables in varying intensities (Adisasmita, 2008). From a geographical point of view, a growth pole is an area that has many facilities and supportive conditions in such a way that it can be the pole of attraction (Nugroho and RokhminDahuri, 2004 in Rahayu and Eko Budi Santoso, 2014). In the context of regional growth and development in West Halmahera Regency, the developmental efforts are focused on the creation and development of growth poles. To fulfill its main function, regional development must be associated to its hinterland especially as the centers of trading and marketing of a variety of agricultural and horticultural commodities. This means that functional interdependability between the growth pole and its hinterland becomes the focal point for the developmental efforts in West Halmahera Regency, which consists of 8 subdistricts and 176 villages that encompasses an area of $14,823.16 \mathrm{~km}^{2}$. It is a large potential area that needs to be strategically managed and developed. The growth poles need to be determined carefully in order to encourage the continual growth of their hinterland areas. In order to do that, the subdistricts in West Halmahera Regency need to be identified to determine the ones most appropriate to be developed as new growth poles with the expectations that the creation of new growth poles along with their economic and infrastructural developments will spread out to their hinterland areas and eventually create equally developed areas.

\section{Objective of The Study}

This study is aimed to determine the subdistricts that are most appropriate to be developed as the new economic growth poles in West Halmahera Regency. 


\section{Literature Review}

Siregar (2015) in his study "Application of Location Quotient and Scalogram Model to Support New Growth Centre in the Border Region of Medan City", with using scalogram analysis, found that there were 5 orders in a subdistrict with the highest position located in order 1, and that there were yearly fluctuations in the positioning of the orders in a subdistrict that were caused by the growing number of populations. Based on location quotient analysis results, it was found that there were new growth poles in the peripheral areas of Medan City, along with the growing number of Industrial Districts in Medan into 5 industrial districts that created new job opportunities. There were also new growth poles in the central district with the constructions of a new highway, a railway, the Kualanamo Airport and also new hotels and shopping malls.

Ermawati (2010) in her study, "Analysis of the Economic Growth Center At Subdistrict Level InKaranganyar, Central Java Province", employed Scalogram analysis and Index of Centrality, Gravitational/Interactional Analysis, Klassen Typology and Location Quotient Analysis. Results from Scalogram analysis and the Index of Centrality showed that there were 7 subdistricts that reach a hierarchy of a higher category as the new growth poles, namely: SubdistrictKaranganyar, SubdistrictJaten, SubdistrictTasikmadu, SubdistrictColomadu, SubdistrictTawangmangun, SubdistrictKarangpandan, and SubdistrictGondangRejo.

Sutikno and Maryunani (2007) in their study, "Analysis of Potential and Competitiveness SubdistrictAs Growth Centre of Regional Unit Development (RUD) Malang Regency", employed Klassen Typology, Location Quotient (LQ), Shift-Share (SS), Scalogram and Competitive Advantages Analyses. Based on the results of Scalogram, Competitive Advantages and Distance analyses, the growth poles in each RUD can be revealed: SubdistrictNgantang was the priority subdistrict for RUD I; SubdistrictSingosari was the priority subdistrict for Northern RUD II; SubdistrictPakisaji was the priority subdistrict for Southern RUD II; SubdistrictPoncokusumu was the priority subdistrict for SWP IV; SubdistrictKepanjen was the priority subdistrict for RUD V; SubdistrictPagelalaran was the priority subdistrict for RUD VII; Subdistrict Turin was the priority subdistrict for RUD VIII.

Ardila (2012) in their study "Analysis of Development of Economic Growth Center in Banjarnegara Regency", with using scalogram analysis and index of centrality, Klassen typology and Location Quotient analyses, identified 6 subdistricts that can be categorized as growth poles namely SubdistrictBanjarnegara, Madukara, Purwanegara, Mandiraja, PurwarejaKlampok and Susukan. Interactions were found and the scores of interactions between the growth poles and their hinterland areas were variable. The majority of subdistricts were still relatively underdeveloped. The basic sectors were on average distributed evenly in 20 subdistricts in Banjarnegara Regency, but the most dominant basic sectors were agricultural sector, electricity, gaseous fuel and water sector, construction sector, and services.

In their study Saleh, Yazid, et al (2011), "Model HierarkiKefungsiandan Pusat Pertum buhanse bagai Asasbagi Merancang Kawasan Luar Bandar DI Malaysia: Buktidari Daerah Batang Padang,"aimed to demonstrate that functional hierarchy model and growth pole strategy are still relevant as the foundation for the developmental planning of rural areas in Malaysia. Results showed that based on the number of populations, the hierarchical settlement patterns in the study area were not evenly distributed. However, using functional analysis in the settled areas, a different pattern revealed. TanjongMalim City was on the highest hierarchical order as the central area in the region, followed by Bidor and Tapah. The central government's objective was to alter TanjongMalim as the sub-regional center in Perak District especially in accordance with the context of Bernam Valley Zone Planning pertaining to strategic reinforcement of TanjongMalim's function as the centers of higher educational and automotive sectors. It shows that functional hierarchy model and growth pole strategy are still relevant as the foundation for developing plans of rural areas in Malaysia.

In her study, Utami (2014), identified facilities development in subdistrict Cibinong and examined the role of subdistrict Cibinong as the center of economic growth in Bogor Regency and the structural changes of the workforce in subdistrict Cibinong. The study was a quantitative descriptive study. The data used were secondary data obtained from Central Bureau of Statistics (BPS) and Development Planning Agency (BAPPEDA) in Bogor regency from observation year of 2005, and PODES 2011 data from Population Census 2000 and 2010. The quantitative analysis used in the study was Scalogram analysis, transformation of the workforce and a descriptive analysis. Results showed that the highest score for facilities was in subdistrict Cibinong. Subdistrict Cibinong acts as the growth pole of economic development in Bogor regency (hierarchy 1). The structure of the workforce in subdistrict Cibinong changed from predominantly agricultural sector to predominantly manufacturing and service sectors.

\section{Research Methodology}

The data used in this study are secondary data obtained from both relevant institutions and from literature. The data collection method is bibliographical surveys of published literature and internet browsing through which the researchers examined the data both quantitatively and qualitatively (reports, regional 
monographs, scientific journals and books, etc.). Scalogram analysis is used in this study to analyze data with the purpose to identify subdistricts that can be categorized as growth poles based on the available facilities in those subdistricts. The hierarchical order of each region is subsequently determined based on the total number of available facilities in that particular region. The stages in scalogram analysis method are as follows: (1) Subdistricts in each region are ranked based on the number of their population; (2) Subdistricts in each region are ranked based on the number and types of available facilities; (3) Facilities are ranked based on the number of subdistricts that have them available; and (4) Types of facilities are ranked based on the total number of each unit of the facility.

\section{Results and Discussions}

Identifying the Status of Each Subdistrict in West Halmahera Regency.

For the purpose of this analysis, the data used are the types of socioeconomic infrastructures and regional accessibility data, such as travelled distance and travelled time between subdistricts and their subdistricts' capitals, between subdistricts and their central regencies, and between subdistricts and the nearest neighboring regencies. The nine subdistricts in this unit of analysis can be grouped into three categories: Hierarchy I (relatively developed regions), Hierarchy II (moderately developed regions), and Hierarchy III (relatively under-developed regions). Analysis results based on the availability of socioeconomic infrastructures in each subdistrict revealed that subdistrict jello has the higher the Index of Subdistrict Growth (ISG) at 21.3433 with 17 types of available infrastructures. The lowest subdistrict with an Index of Subdistrict Growth (ISG) at 6.5200 is Kecamatan Ibu Selatan with 13 types of available infrastructures. It can be concluded that the development rates of each subdistrict in West Halmahera Regencyare relatively similar. Of the nine subdistricts analyzed in this study, only one subdistrict reaches a development level within Hierarchy II, while the other eight fall within Hierarchy III. The results data are shown in Table 1 below.

Table 1. Results Of Scalogram Analysis On The Sosioeconomic Infrastructures Within Subdistrics In West Halmahera Regency In 2013

\begin{tabular}{|l|l|l|l|l|l|l|}
\hline No & Subdistricts & $\begin{array}{l}\text { Total population } \\
\text { (Person) }\end{array}$ & $\begin{array}{l}\text { Size subdistrict } \\
\text { area (Ha) }\end{array}$ & IPK & $\begin{array}{l}\text { Number type } \\
\text { Infrastructure }\end{array}$ & Hierarchy \\
\hline 1 & Jailolo Timur & 3,498 & 281.35 & 21.3433 & 17 & 2 \\
\hline 2 & Jailolo & 28,205 & 226.00 & 11.2889 & 22 & 3 \\
\hline 3 & Jailolo Selatan & 14,485 & 147.55 & 10.5120 & 19 & 3 \\
\hline 4 & Sahu & 9,446 & 122.86 & 9.6571 & 15 & 3 \\
\hline 5 & Sahu Timur & 8,208 & 271.00 & 12.2677 & 16 & 3 \\
\hline 6 & Ibu & 9,577 & 109.82 & 7.2921 & 14 & 3 \\
\hline 7 & Ibu Selatan & 10,584 & 368.33 & 6.5200 & 13 & 3 \\
\hline 8 & Ibu Utara & 7,961 & 220.64 & 6.6278 & 13 & 3 \\
\hline 9 & Loloda & 10,881 & 614.01 & 10.2191 & 15 & 3 \\
\hline
\end{tabular}

Source: West Halmahera Regencyin Numbers, 2014. Processed Data.

\section{The Availability of Educational Infrastructures Within Subdistricts.}

As seen in Table 2, West Halmahera Regencyhas 325 units of educational infrastructures with average distributions 36 units in each subdistrict. Judging from its number of populations, subdistrict Loloda, which is located relatively far away from the subdistrict's capital, has a relatively higher need for educational facilities. The number of populations in 2013 was 614.01 individuals, with only 38 units of educational infrastructures. This condition compares unfavorably to subdistrict Jailolo Selatan with populations of 147.55 individuals and which has 51 units of educational infrastructures.

Table 2. Results Of Scalogram Analysis On The Education Infrastructures Within Subdistrics In West Halmahera Regency In 2013

\begin{tabular}{|c|c|c|c|c|c|c|c|c|c|}
\hline \multirow[t]{2}{*}{ No } & \multirow[t]{2}{*}{ Subdistricts } & \multirow{2}{*}{$\begin{array}{l}\text { Total } \\
\text { Population } \\
\text { (Person) }\end{array}$} & \multirow{2}{*}{$\begin{array}{l}\text { Size } \\
\text { Subdistrict } \\
\text { Area }(\mathrm{Ha})\end{array}$} & \multicolumn{5}{|c|}{ Facilities of Education (unit) } & \multirow{2}{*}{$\begin{array}{l}\text { Total } \\
\text { Unit }\end{array}$} \\
\hline & & & & TK & SD & SLTP & SLTA & PT & \\
\hline 1 & Jailolo & 28,205 & 226.00 & 9 & 37 & 15 & 8 & 1 & 70 \\
\hline 2 & Jailolo Timur & 3,498 & 281.35 & 1 & 36 & 4 & 3 & 0 & 44 \\
\hline 3 & Jailolo Selatan & 14,485 & 147.55 & 6 & 27 & 13 & 5 & 0 & 51 \\
\hline 4 & Sahu & 9,446 & 122.86 & 3 & 15 & 8 & 2 & 0 & 28 \\
\hline 5 & Sahu Timur & 8,208 & 271.00 & 3 & 14 & 5 & 5 & 0 & 27 \\
\hline 6 & Ibu & 9,577 & 109.82 & 0 & 15 & 5 & 2 & 0 & 22 \\
\hline 7 & Ibu Selatan & 10,584 & 368.33 & 0 & 17 & 6 & 2 & 0 & 25 \\
\hline 8 & Ibu Utara & 7,961 & 220.64 & 0 & 14 & 4 & 2 & 0 & 20 \\
\hline 9 & Loloda & 10,881 & 614.01 & 0 & 30 & 7 & 1 & 0 & 38 \\
\hline \multicolumn{2}{|c|}{ Amount } & 102,845 & 22.6155 & 22 & 205 & 67 & 30 & 1 & 325 \\
\hline \multicolumn{2}{|c|}{ Average } & 11,427 & & 2 & 23 & 7 & 3 & 0 & 36 \\
\hline
\end{tabular}

Source: West Halmahera Regencyin Numbers, 2014. Processed Data. 


\section{Note: TK is Kindergarten SD is Elementary school SLTP is Secondary school SLTA is High School}

\section{The Availability of Transportational Infrastructures Within and Between Subdistricts.}

Another vital social infrastructure that needs to be addressed by the government is transportation infrastructure. As an archipelago region, the North Moluccas Province vitally needs transportation infrastructures to promote economic activities and to support the interactions of its demographic populations. An all around transportation infrastructure shall increase inter-regional socioeconomic mobility of goods and services. In turn, regional inflations can be curbed or controlled and inter-regional connectivities can be intensified which will promote the development of regional economic infrastructures.

As seen in Table 3, results of scalogram analysis on transportation infrastructures within and between subdistricts in West Halmahera Regencyin 2013 showed that subdistrict Jailolo has the highest number of transportation infrastructures, as many as 2 units, which are 1 unit of seaport for small boats and/or large ships and 1 unit of public transportation terminal. There is no airport in subdistrict Jailolo. And for subdistrict Loloda, particularly, which is geographically different from Halmahera island, the construction of road access and seaport are vitally important to render this region less isolated and create a more effective inter-regional connectivity.

Table 3. Results Of Scalogram Analysis On The Transportation Infrastructures Within And Between Subdistricsin West Halmahera Regency In 2013

\begin{tabular}{|c|c|c|c|c|c|c|}
\hline \multirow[t]{2}{*}{ No } & \multirow[t]{2}{*}{ Subdistricts } & \multirow{2}{*}{$\begin{array}{l}\text { Total Population } \\
\text { (Person) }\end{array}$} & \multirow{2}{*}{$\begin{array}{l}\text { Size Subdistrict } \\
\text { Area }(\mathrm{Ha})\end{array}$} & \multicolumn{2}{|c|}{ Facilities of Transportation (unit) } & \multirow[t]{2}{*}{ Total unit } \\
\hline & & & & Station Land & Seaport & \\
\hline 1 & Jailolo & 28,205 & 226.00 & 1 & 1 & 2 \\
\hline 2 & Jailolo Timur & 3,498 & 281.35 & 0 & 0 & 0 \\
\hline 3 & Jailolo Selatan & 14,485 & 147.55 & 0 & 0 & 0 \\
\hline 4 & Sahu & 9,446 & 122.86 & 0 & 0 & 0 \\
\hline 5 & Sahu Timur & 8,208 & 271.00 & 0 & 0 & 0 \\
\hline 6 & Ibu & 9,577 & 109.82 & 0 & 0 & 0 \\
\hline 7 & Ibu Selatan & 10,584 & 368.33 & 0 & 0 & 0 \\
\hline 8 & Ibu Utara & 7,961 & 220.64 & 0 & 0 & 0 \\
\hline 9 & Loloda & 10,881 & 614.01 & 0 & 0 & 1 \\
\hline \multicolumn{2}{|c|}{ Amount } & 102,845 & 22.6155 & 1 & 1 & 3 \\
\hline
\end{tabular}

Source: West Halmahera Regencyin Numbers, 2014. Processed Data.

The Availability of Health Care Infrastructures Within Subdistricts.

As can be seen in Table 4, subdistrict with the least amount of healthcare infrastructure is subdistrict Jailolo Timur that only has 12 units of healthcare facilities. On average, the number of healthcare infrastructures in each subdistrict is 27 units. Compared to the number of populations in each subdistrict, the total availability of healthcare infrastructures in each subdistrict is relatively equal. However, judging from the distributional patterns of primary healthcare infrastructures such as hospitals, local clinics, midwifery, pustu/polindes, posyandu, private physician practices, and pharmacies, it can be concluded that these primary healthcare infrastructures are not evenly distributed in each subdistrict. The primary healthcare infrastructures are more concentrated in subdistrict Jailolo as the capital of West Halmahera Regency.

As can be seen in Table 4, subdistrict with the least amount of healthcare infrastructures is subdistrict Jailolo Timur that only has 12 units of healthcare facilities. However, the total availability of healthcare infrastructures in the whole regency is 248 units. Thus, on the average numbers of healthcare infrastructures in each subdistrict are 27 units. Compared to the number of populations in each subdistrict, the total availability of healthcare infrastructures in each subdistrict is relatively equal. The relatively higher populations in a certain subdistrict are balanced with the availability of healthcare infrastructures in that subdistrict. However, judging from the distributional patterns of primary healthcare infrastructures such as hospitals, local clinics, midwifery, pustu/polindes, posyandu, private physician practices, and pharmacies, it can be concluded that these primary healthcare infrastructures are not evenly distributed in each subdistrict. The primary healthcare infrastructures are more concentrated in subdistrict Jailolo as the capital of West Halmahera Regency.

Table 4. Results Of Scalogram Analysis On Health Care Infrastructures Within Subdistrics In West Halmahera Regency.

\begin{tabular}{|c|c|c|c|c|c|c|c|c|c|}
\hline \multirow[t]{2}{*}{ No } & \multirow[t]{2}{*}{ Subdistricts } & \multirow{2}{*}{$\begin{array}{l}\text { Total } \\
\text { Population } \\
\text { (Person) }\end{array}$} & \multirow{2}{*}{$\begin{array}{l}\text { Size } \\
\text { Subdistrict } \\
\text { Area (Ha) }\end{array}$} & \multicolumn{5}{|c|}{ Facilities of Health (Unit) } & \multirow{2}{*}{$\begin{array}{l}\text { Total } \\
\text { Unit }\end{array}$} \\
\hline & & & & Hospital & $\begin{array}{l}\text { Health } \\
\text { Center }\end{array}$ & $\begin{array}{l}\text { Village } \\
\text { Polyclinic }\end{array}$ & $\begin{array}{l}\text { Place Integrated } \\
\text { Health Services }\end{array}$ & Apotik & \\
\hline 1 & Jailolo & 28,205 & 226.00 & 1 & 1 & 10 & 36 & 7 & 55 \\
\hline 2 & Jailolo Timur & 3,498 & 281.35 & 0 & 1 & 5 & 6 & 0 & 12 \\
\hline 3 & Jailolo Selatan & 14,485 & 147.55 & 0 & 1 & 13 & 9 & 0 & 23 \\
\hline 4 & Sahu & 9,446 & 122.86 & 0 & 1 & 8 & 20 & 0 & 29 \\
\hline 5 & Sahu Timur & 8,208 & 271.00 & 0 & 2 & 5 & 18 & 0 & 25 \\
\hline
\end{tabular}


Determining The Centers Of Economic Growth And Regional Development Using Scalogram

\begin{tabular}{|l|l|l|l|l|l|l|l|l|l|}
\hline 6 & Ibu & 9,577 & 109.82 & 0 & 1 & 4 & 14 & 0 & 19 \\
\hline 7 & Ibu Selatan & 10,584 & 368.33 & 0 & 1 & 6 & 17 & 0 & 24 \\
\hline 8 & Ibu Utara & 7,961 & 220.64 & 0 & 1 & 3 & 14 & 0 & 18 \\
\hline 9 & Loloda & 10,881 & 614.01 & 0 & 1 & 10 & 32 & 0 & 0 \\
\hline Amount & 102,845 & & 1 & 10 & 64 & 166 & 43 & 0 & 248 \\
\hline Average & 11,427 & & 2 & 23 & & 18,4 & 0 & 27.6 \\
\hline
\end{tabular}

Source: West Halmahera Regencyin Numbers, 2014. Processed Data.

The Availability of Economic Infrastructures Within Subdistrict.

Table 5. Results Of Scalogram Analysis On Economic Infrastructures Within Subdistrics In West Halmahera Regency.

\begin{tabular}{|c|c|c|c|c|c|c|c|c|c|}
\hline \multirow[t]{2}{*}{ No } & \multirow[t]{2}{*}{ Subdistricts } & \multicolumn{5}{|c|}{ Facility Industry \& Trade (unit) } & \multirow[b]{2}{*}{ Shops } & \multirow[b]{2}{*}{ Hotels } & \multirow{2}{*}{$\begin{array}{l}\text { Total } \\
\text { Unit }\end{array}$} \\
\hline & & $\begin{array}{l}\text { Stall of Agricultural } \\
\text { Facilities }\end{array}$ & $\begin{array}{l}\text { Large } \\
\text { Industries }\end{array}$ & $\begin{array}{l}\text { Small } \\
\text { Industries }\end{array}$ & $\begin{array}{l}\text { Micro } \\
\text { Industries }\end{array}$ & Restaurants & & & \\
\hline 1 & Jailolo & 0 & 0 & 0 & 0 & 15 & 0 & 12 & 27 \\
\hline 2 & Jailolo Timur & 0 & 0 & 0 & 0 & 0 & 0 & 0 & 0 \\
\hline 3 & Jailolo Selatan & 0 & 0 & 0 & 0 & 1 & 0 & 9 & 10 \\
\hline 4 & Sahu & 0 & 0 & 0 & 0 & 0 & 0 & 0 & 0 \\
\hline 5 & Sahu Timur & 0 & 0 & 0 & 0 & 0 & 0 & 3 & 3 \\
\hline 6 & Ibu & 0 & 0 & 0 & 0 & 0 & 0 & 0 & 0 \\
\hline 7 & Ibu Selatan & 0 & 0 & 0 & 0 & 0 & 0 & 0 & 0 \\
\hline 8 & Ibu Utara & 0 & 0 & 0 & 0 & 0 & 0 & 0 & 0 \\
\hline 9 & Loloda & 0 & 0 & 0 & 0 & 0 & 0 & 1 & 1 \\
\hline \multicolumn{2}{|c|}{ Amount } & 0 & 0 & 0 & 0 & 16 & 0 & 25 & 41 \\
\hline \multicolumn{2}{|c|}{ Average } & 0 & 0 & 0 & 0 & 2 & 0 & 3 & 4.6 \\
\hline
\end{tabular}

Source: West Halmahera Regencyin Numbers, 2014. Processed Data.

As seen in Table 5, results from scalogram analysis showed that subdistrict with the highest number economic infrastructures (Industrial, Services and Trading Facilities) is subdistrict Jailolo with as many as 27 units. On the opposite of the scale, there are five subdistricts with the least economic infrastructures namely, subdistrict Jailolo Timur, subdistrict Sahu, subdistrict Ibu, subdistrict Ibu Selatan, and subdistrict Ibu Utara. On average, each subdistrict in West Halmahera Regencyhas 4 units of economic infrastructures. As detailed in tables 5 and 6 , the most recorded economic infrastructures available are restaurants/diners and hotels. Another common economic infrastructures, with as many as 71 units, are banking services which consist of banks and 67 cooperative/non-cooperative banks. Subdistrict with the least number of economic infrastructures is subdistrict Ibu Utara, with only 4 units in total which consist of 1 unit of cooperative bank and 3 units of noncooperative banks.

So, as seen in Table 6, results from scalogram analysis showed that, on average, each subdistrict has 1 unit of KUD and 17 units of Non-KUD Cooperatives. Subdistrict with the highest number of both KUD and Non-KUD Cooperatives are subdistrict Jailolo that has 3 units of KUD dan 64 units of Non-KUD Cooperatives. Judging from the number of its population, subdistrict Jailolo has the highest economic activities in the whole regency. Moreover, subdistrict Jailolo is the center of administrative activities in West Halmahera Regencyand also as the main destination for students looking for higher education facilities. As a consequence, subdistrict Jailolo also has relatively higher numbers of restaurants/diners and hotels/lodgings than other subdistricts. And last but not least, there are other vital economic infrastructures such as banking services and cooperative banks in each subdistrict in West Halmahera Regency.

Table 6. Results Of Scalogram Analysis On Economic Infrastructures Within Subdistrics In West Halmahera Regency.

\begin{tabular}{|c|c|c|c|c|c|c|c|c|}
\hline \multirow[t]{2}{*}{ No } & \multirow[t]{2}{*}{ Subdistricts } & \multirow{2}{*}{$\begin{array}{l}\text { Total } \\
\text { Population } \\
\text { (Person) }\end{array}$} & \multirow{2}{*}{$\begin{array}{l}\text { Size Subdistrict } \\
\text { Area }(\mathrm{Ha})\end{array}$} & \multicolumn{4}{|c|}{ Facility Banking \& Cooperative } & \multirow{2}{*}{$\begin{array}{l}\text { Total } \\
\text { unit }\end{array}$} \\
\hline & & & & Banks & $\begin{array}{l}\text { Rural } \\
\text { Banks } \\
\text { (BPR) }\end{array}$ & Cooperative & $\begin{array}{l}\text { Amount Cooperatives } \\
\text { non village Unit } \\
\text { Cooperatives }\end{array}$ & \\
\hline 1 & Jailolo & 28,205 & 226.00 & 4 & 0 & 3 & 64 & 71 \\
\hline 2 & Jailolo Timur & 3,498 & 281.35 & 0 & 5 & 1 & 6 & 12 \\
\hline 3 & Jailolo Selatan & 14,485 & 147.55 & 1 & 0 & 2 & 20 & 23 \\
\hline 4 & Sahu & 9,446 & 122.86 & 0 & 3 & 1 & 13 & 17 \\
\hline 5 & Sahu Timur & 8,208 & 271.00 & 0 & 2 & 2 & 8 & 12 \\
\hline 6 & Ibu & 9,577 & 109.82 & 1 & 0 & 1 & 14 & 16 \\
\hline 7 & Ibu Selatan & 10,584 & 368.33 & 0 & 0 & 1 & 9 & 10 \\
\hline 8 & Ibu Utara & 7,961 & 220.64 & 0 & 0 & 1 & 3 & 4 \\
\hline 9 & Loloda & 10,881 & 614.01 & 0 & 0 & 1 & 17 & 18 \\
\hline \multicolumn{2}{|c|}{ Amount } & 102,845 & \multicolumn{2}{|l|}{6} & 10 & 13 & 154 & 183 \\
\hline \multicolumn{2}{|c|}{ Average } & 11,427 & \multicolumn{2}{|l|}{1} & 1 & 1 & 17 & 20 \\
\hline
\end{tabular}

Source: West Halmahera Regencyin Numbers, 2014. Processed Data. 


\section{Conclusions}

Of the nine subdistricts examined in this study, only four subdistricts have the highest scores of socioeconomic infrastructures completeness, namely: subdistrict Jailolo, subdistrict Jailolo Selatan, subdistrict Jailolo Timur, and subdistrict Sahu Timur. Subdistrict Jailolo is located in the center of regional administrative activities in West Halmahera Regency. And thus, subdistrict Jailolo acts as the growth pole in the region and the other three subdistricts act as buffer areas. Subdistrict with the least complete of socioeconomic infrastructures is Subdistrict Ibu Utara. Based on scalogram analysis it was revealed that the development within each subdistrict in West Halmahera Regencywas more or less relatively similar. Of the nine subdistricts analyzed in this study, only one subdistrict shows a relatively better development (Hierarchy II) with the highest Index of Subdistrict Growth (ISG) which is none other than subdistrict Jailolo. Meanwhile, the other eight subdistricts are less-developed and/or under-developed (hirarki III) with a variable Index of Subdistrict Growth (ISG).

\section{References}

[1] Adisasmita, Rahardjo. TeoriLokasidanPengembangan Wilayah, (Makassar: UniversitasHasanuddin Press, 2008)

[2] Mardila, Refika, AnalisisPengembanganPusatPertumbuhanEkonomi di KabupatenBanjarnegara. Economics Development Analysis Journal 1 (2) , 2012. [Online] Available: http://journal.unnes.ac.id/sju/index.php/edaj.

[3] Erawatie, EliaDia, KajianTentang Status, Perubahan Struktur Ekonomidan Potensi Wilayah Kabupaten Magelang Sebelumdan Selama Otonomi Daerah 1998-2008),Skripsi. Tidakdipu blikasikan. Surakarta: Fakultas Ekonomi UniversitasSebela sMaret Surakarta, 2009.

[4] Isnina, WahyuningSaptaUtami, AnalisisPeranKecamatan Cibinong Sebagai Pusat Pertumbuhan Ekonomi. Jurnal Organisasidan Manajemen, Volume 10, Nomor 2, September, 2014.

[5] Panjiputri, AgataFebrina, AnalisisPotensiPengembanganPusatPertumbuhanEkonomi Di KawasanStrategisTangkallangka.Economics Development Analysis Journal. 2 (3), 2013. [Online] Available: http://journal.unnes.ac.id/sju/index.php/edaj.

[6] Yazid,Saleh, KatimanRostam, MohdYusofHussain., GEOGRAFIA Online ${ }^{T M}$ Malaysian Journal of Society and Space7.Special Issue: Social and Spatial Challenges of Malaysian Development.pp: 66-79, 2011.

[7] Siregar, OktariniKhamilah, Penerapan Model Location Quotient Dan ScalogramDalamMendorongPusatPertumbuhanBaru Di Wilayah Perbatasan Kota Medan. Seminar Nasional Ekonomi Manajemendan Akuntansi (SNEMA) Fakultas Ekonomi Universitas Negeri Padang., 2015. [Online] Available: http://fe.unp.ac.id/.

[8] SutiknodanMaryunani, AnalisisPotensi Dan DayaSaingKecamatanSebagaiPusatPertumbuhanSatuan Wilayah Pengembangan (SWP) Kabupaten Malang. Journal of Indonesian Applied Economics, Vol.1 No.1 October, 2007,Hal: 1-17.

[9] Rustiadi, E.S,Saefulhakim, dan D. R. Panuju., PerencanaandanPengembangan Wilayah. Jakarta: Crestpent Press danYayasanObor Indonesia, 2009.

[10] Sjafrizal, Ekonomi Wilayah danPerkotaan. Jakarta: Rajawali Press, 2012.

[11] Rahayu, Eta danEko Budi Santoso, PenentuanPusat-PusatPertumbuhanDalamPengembangan Wilayah Di Kabupaten Gunung KidulJurnal Teknik Pomits. Vol. 3, No. 2, 2014.

[12] Setiono, Dedi NS, EkonomiPengembangan Wilayah: TeoridanAnalisis. Jakarta: LembagaPenerbit FE UI, 2011. 